UDC 811.111:379.85

DOI https://doi.org/10.32838/2663-6069/2020.2-2/44

Yurko N. A.

Lviv State University of Physical Culture named after Ivan Boberskyi

Styfanyshyn I. M.

Lviv State University of Physical Culture named after Ivan Boberskyi

Protsenko U. M.

Lviv State University of Physical Culture named after Ivan Boberskyi

Romanchuk O. V.

Lviv State University of Physical Culture named after Ivan Boberskyi

\title{
DENUMERALS IN THE ENGLISH TOURISM TERMINOLOGY
}

The article deals with the denumeral features of English tourism terminology. Comprehension of quantitative relationships is reflected in different languages, specifically in English. Therefore, there is a need for systemic investigation of quantitative units in English terminology of various spheres, in particular the area of international travel as one of the fastest growing industries in the world. Due to the necessity to study quantitative terms of travel industry and its evident gaps in the English language, the aim of the research was to examine the denumeral issues of English tourism terminology. The purpose of the study comprised identifying and exploring the denumeral features of English tourism terms. The object of research was the English tourism terminology, and the subject concerned the denumeral characteristics of the English tourism terms. Methods of research: literature analysis, comparative method and method of system analysis. The material under research was the sample of English tourism terms from printed and internet resources. The results of the study preconditioned comprehensive analysis of denumeral issues and defining the quantitative ratio of their productivity in the English tourism terminology. Based on the research findings, the following conclusions were made. English tourism terms feature the adjectival, substantive and adverbial denumerals. Adjectival denumerals are the most peculiar for English tourism terminology. English denumerals of tourism industry are represented by simple, compound and compound derivative types. The study revealed the simple and compound denumerals to be the most common in the area of tourism. The English denumerals of compound and compound derivative types are most productively displayed by the pattern $\mathrm{Num}+N$, which is predetermined by the subject meaning of noun, as one of the most common parts of speech in any professional terminology, particularly in the area of international travel. The perspectives of further research have been defined as the terms systematization and compiling a tourism glossary considering the denumeral features of English terminology in the field of tourism.

Key words: denumerals, professional terminology, quantitative characteristics, English terms, tourism.

\section{Introduction}

Quantity, as well as quality, is one of the most common features of human life. The concept of measure and weight appeared at the beginning of human development and played a significant role in daily activities. Quantification and measurement remain to be of great importance in the life of any society. Study of quantitative characteristics of objects and phenomena is essential in the process of man's cognition and understanding of the environment.

Statement of the problem. Comprehension of quantity and quantitative relationships is reflected in different languages. In English, the quantification of objects is displayed by morphological, lexical, word-forming and syntactic means, which are closely related and interdependent, permeating the entire system of the English language [8, p. 19]. This, therefore, necessitates systemic investigation of quantitative units in English terminology of various spheres, in particular the area of international travel as one of the fastest growing industries in the world.

Recent studies and publications. The overview of previous research provides clear evidence of great attention being paid to analysis of different termi- 
nological systems $[1 ; 3 ; 4 ; 6 ; 9 ; 15]$. Some recent surveys have also been focused on various aspects in the field of international travel $[7 ; 12 ; 14 ; 16 ; 17$; $18 ; 19]$. Few researchers referred to quantitative lexical units of the English language $[2 ; 8 ; 10]$ as well. Much survey, though, remains to be done in terms of denumeral issues of English terminology in tourism sphere.

Purpose and objectives of the article. In view of the actual need to study quantitative terms of travel industry and its evident gaps in the English language, the aim of the research is to examine the denumeral issues of English tourism terminology. Objectives of the study include identifying and exploring the denumeral features of English terms in the field of tourism. Consequently, the object of research is the English terminology of tourism industry, and the subject concerns the denumeral characteristics of the English tourism terms. Methods of research: literature analysis, comparative method and method of system analysis. The material under research is represented by the sample of English tourism terms from printed $[5 ; 13]$ and internet $[11]$ resources.

\section{Main material.}

Numerals, like any part of speech, are capable of word-building potentials. The ability of numerals to form new lexical units contributes significantly to vocabulary enhancement of the language. One of the features of dynamic word-building peculiar to English numerals is the formation of denumerals, secondary structures beyond one part of speech. By denumeral we mean the secondary construction, the initial morpheme for which is the root morpheme of the numeral [8, p. 138]. Shvachko S. distinguishes adverbial, adjectival, substantive and auxiliary denumerals.

Due to analysis of the research database, the main denumeral groups of English terms in the area of tourism appear to be the following:

- adjectival (biennial festival, double booking, first-class accommodation, first course, five-star rating system, four-poster bed, half-price offer, multiple visa, one-way ticket, second-class hotel, single supplement, third-party insurance, triple room, twin-bedded room, two-bedroomed bungalow, etc.);

- substantive (double-decker, duopoly, duplex, monorail, single-decker, twinning, two-seater, etc.);

- adverbial (to travel first class, etc.).

The sample under research have shown to be particularly well-presented by the adjectival denumerals $(92.8 \%)$, while the substantive denumerals proved to be less productive $(6.3 \%)$. The adverbial denumerals are rather occasional and account for less than $1 \%$ of the terms sample, and no auxiliary denumerals are found to be observed in the research database. The quantitative prevalence of the adjectival denumerals is preconditioned by their features of definitional function and differential attribute of any notion, particularly in the field of international travel.

Denumeral derivatives are distinguished to be simple, complex and compound denumerals [8, p. 137]. The study findings suggest that English denumerals of tourism industry reveal to be represented by each of the three types:

- simple $-46.3 \%$ (double bed, double booking, double occupancy, double room, first class of service, first course, half board, single occupancy, single price, single room, single supplement, single trip, sole agent, sole trader, triple room, twin beds, twin towers, twin town, etc.);

- compound - 41.6\% (first-rate service, fivestar hotel, four-star restaurant, half-day excursion, number-one destination, one-man tent, second-class ticket, single-entry visa, third-class travel, threecourse dinner, two-star hotel, etc.);

- compound derivative - $12.1 \%$ (double-decker, multi-bedded room, semi-skilled job, single-decker, twin-bedded room, two-bedroomed bungalow, twoseater, etc.).

The above percentage points out the evident dominance of simple and compound denumerals in the English tourism terminology. This prevalence is naturally predetermined by the common claiming that the term contradiction in conciseness and precision are the least peculiar for these terms.

The English denumerals of the compound and compound derivative types are found to be displayed in the research material by the following patterns:

- Num+N-72.1\% (first-class accommodation, first-rate service, five-star restaurant, four-star hotel, half-day excursion, half-price offer, one-man tent, one-time entry, one-way fare, second-class ticket, second-rate accommodation, single-entry visa, single-ride ticket, third-class travel, third-party insurance, three-course dinner, two-star hotel, etc.);

- Num+N-ed - 14.9\% (half-ruined castle, half-timbered house, multi-bedded room, semiskilled job, twin-bedded room, twin-spired cathedral, two-bedroomed bungalow, etc.);

- Num+N-er - 8.5\% (double-decker, double-decker bus, single-decker, two-seater, etc.);

- Num+N-ing $-2.4 \%$ (double booking, etc.);

- $\mathrm{N}+\mathrm{Num}-2.1 \%$ (number-one destination, etc.).

The above data clearly illustrate the prevailing productivity of the $\mathrm{Num}+N$ pattern in English 
denumeral terminology of tourism industry. This apparent productiveness of substantive component in the denumeral structures of English tourism terms is explained by the fact that noun, denoting the subject meaning, is one of the most common parts of speech in professional terminology, particularly in the area of tourism.

\section{Conclusions.}

Despite the growing bulk of research on different issues in the area of tourism, there was still a need for detailed analyses of denumeral features in the English terminology of tourism sphere.

English tourism terminology features the three main groups of denumerals: adjectival, substantive and adverbial. Adjectival denumerals, due to their definitional function and differential attribute of any notion, are the most peculiar (92.8\%) for English terms in the field of tourism.

The research database analysis suggests that English denumerals of tourism industry are represented by simple, compound and compound derivative types. The study reveals the simple (46.3\%) and compound $(41.6 \%)$ denumerals to be the most common in the area of tourism, the fact being predetermined by the main term requirements for conciseness and precision.

The English denumerals of compound and compound derivative types in the material under research are most productively displayed by the pattern $N u m+N(72.1 \%)$. The evident productiveness of its substantive component in the denumeral structures of English tourism terms is preconditioned by the subject meaning of noun, as one of the most common parts of speech in any professional terminology, particularly in the area of international travel.

The perspectives of further research are the terms systematization and compiling a tourism glossary considering the denumeral features of English terminology in the field of tourism.

\section{References:}

1. Боровська О., Юрко Н. Уживання запозичень у термінології гандболу. Вісник Національного університету «Львівська політехніка». Серія «Проблеми української термінологї̈». 2007. № 593. С. 87-89.

2. Кобякова І.К., Швачко С.О. Лингвистические атрибуты английских числительных и денумеративов. Записки з романо-германської філології. 2019. Вип. 2(43). С. 136-148. DOI 10.18524/2307-4604.2019.2(43). 186298.

3. Коваль Р.С. Структурні моделі термінів для найменування засобів та методів реабілітації у французькій та українській мовах. Молодий вчений. 2019. № 4.2(68.2). С. 101-104.

4. Литвин А.А., Юрко Н.А., Стифанишин І.М. Лінгвальна характеристика інновацій англійської мови соціальної мережі FACEBOOK. Наукові записки Начіонального університету «Острозька академія». Серія «Філологія». 2018. Вип. 1(69). Ч. 1. С. 258-262. DOI 10.25264/2519-2558-2018-1(69)/ $1-258-262$.

5. Мальська М.П., Микитенко Н.О., Котловський А.М. Англо-український словник термінів сфери туризму : навч. посіб. Київ : Центр учбової літератури, 2015. 448 с.

6. Романчук О.В., Матвіяс О.В., Юрко. Н.А. Термінологія тенісу в англійській та українській мовах. Науковий вісник Волинського національного університету імені Лесі Украйнки. 2009. № 5. С. 212-215.

7. Стифанишин І., Юрко Н., Проценко У., Романчук О. Комунікативні аспекти іншомовної професійної підготовки фахівців сфери туризму. Наукові записки Наиіонального університету «Острозька академія». Серія «Філологія». 2019. Вип. 6(74). С. 200-203. DOI 10.25264/2519-2558-2019-6(74)-200-203.

8. Числівник англійської мови : навч. посіб. для студ. вищ. навч. закл. / С.О. Швачко, С.В. Баранова, І.К. Кобякова та ін. Суми : Вид-во СумДУ, 2010. 171 с.

9. Юрко Н.А. Синонімічні характеристики термінів гандболу в англійській мові. Наукові записки Національного університету «Острозька академія». Серія «Філологічна». 2015. Вип. 56. С. 343-345.

10. Юрко Н., Романчук О., Матвіяс О., Проценко У., Стифанишин І. Словотвірні аспекти денумеральних утворень в англомовній спортивній лексиці. Молода спортивна наука Украӥни. 2012. Вип. 4(16). C. $176-179$.

11. BeaverA. Oxford Dictionary of Travel and Tourism. Oxford: OUP, 2012. URL: http://www.oxfordreference. com/view/10.1093/acref/ 9780191733987.001.0001 (accessed: 24.04.2020).

12. Lytvyn A. Linguocultural parameters of English innovative vocabulary in the field of sports and tourism. Wschodnioeuropejskie Czasopismo Naukowe (East European Scientific Journal). 2017. № 8(24). C. 19-22.

13. Medlik S. Dictionary of travel, tourism and hospitality. Oxford: Butterworth-Heinemann, 2003. 283 p.

14. Yurko N. A. Abbreviations in tourism industry: the main peculiarities of structural components. Akmyальні питання наукових досліджень : матеріали XLIII Міжнар. наук.-практ. конф. (Чернівці, 29-30 червня 2016 р.). Київ : Лабораторія думки, 2016. Т. 2. С. 9-11.

15. Yurko N. A., Styfanyshyn I. M., Protsenko U. M, Romanchuk O. V. The characteristics of word formation in English track-and-field terminology. Закарпатські філологічні студіï. 2019. Вип. 1(9). С. 146-149. 
16. Yurko N. A., Styfanyshyn I. M., Protsenko U. M, Romanchuk O. V. The word-formation features of English terminology in tourism industry. Науковий вісник Міжнародного гуманітарного університету. Серія «Філологія». 2019. Вип. 2(38). С. 185-187.

17. Yurko N., Styfanyshyn I., Protsenko U., Romanchuk O. Tourism English: the fields of occupational benefits. Економіко-соиіальні відносини в галузі фізичної культури та сфери обслуговування : матеріали II Міжнар. наук.-практ. конф. (Львів, 23-24 травня 2019 р.). Львів : ЛДУФК, 2019. С. 66-68.

18. Yurko N. A., Styfanyshyn I. M., Romanchuk O. V. The characteristics of English terms structure in tourism industry. Львівський філологічний часопис. 2019. № 5. С. 178-182. DOI 10.32447/2663-340X-2019-5-30.

19. Yurko N. A., Styfanyshyn I. M., Protsenko U. M, Slodynytska Yu. R. Tourism translation: the key peculiarities. АОГОГ. ОНЛАЙН. 2020. № 7. DOI 10.36074/2663-4139.07.04 URL : https://ojs.ukrlogos.in.ua/ index.php/2663-4139 (accessed: 24.04.2020).

\section{Юрко Н. А., Стифанишин І. М., Проценко У. М., Романчук О. В. ДЕНУМЕРАТИВИ В АНГЛІЙСЬКІЙ ТЕРМІНОЛОГІЇ ТУРИЗМУ}

У статті розглянуто денумеральні особливості англійської туристичної термінології. Розуміння кількісних співвідношень відображено в різних мовах, зокрема в англійській. Відтак є потреба системного дослідження квантитативних одиниць англійської термінологї в різних сферах, особливо в галузі міжнародного туризму, що зазнає досить швидкого розвитку в усьому світі. 3 огляду на необхідність дослідження квантитативних термінів туристичної галузі та очевидні ї̈ прогалини в англійській мові метою нашої розвідки було вивчення денумеральних аспектів англійської туристичної термінології. Мета дослідження полягала у визначенні та дослідженні денумеральних особливостей англійських туристичних термінів. Об'єктом дослідження була англійська туристична термінологія, а предметом дослідження стали денумеральні характеристики англійських туристичних термінів. Методи дослідження: аналіз літературних джерел, компаративний метод та метод системного аналізу. Матеріалом дослідження слугувала вибірка англійських туристичних термінів із друкованих та Інтернет-ресурсів. Результати дослідження зумовлюють детальний аналіз денумеральних аспектів та визначення кількісного співвідношення їх продуктивності в англійській туристичній термінологї. На підставі результатів досліджень зроблено такі висновки. Англійські терміни туризму містять ад'єктивні, субстантивні та адвербіальні денумеративи. Найбільш властивими для англійської туристичної термінології є ад'єктивні денумеративи. Англійські денумеративи туристичної галузі представлені простими, складними та складно похідними термінами. За результатами дослідження, прості та складні денумеративи є найпоширенішими у сфері туризму. Складні та складнопохідні денумеративи найбільш продуктивно відображені в моделі Num $+N$, щзо зумовлено предметним значенням іменника як однієї з найпоширеніших частин мови в будь-якій фаховій термінології, особливо в галузі міжнародного туризму. Перспективними напрямками подальших досліджень було визначено систематизацію та укладання фахового словника туристичних термінів з урахуванням денумеральних особливостей англійської термінології в галузі туризму.

Ключові слова: денумеративи, фахова термінологія, квантитативні характеристики, англійські терміни, туризм. 